\title{
Utero-vaginal prolapse in primigravida: a case report
}

\author{
Seetesh Ghose*, Sunita Samal, Senthil Coumary, Pallavee P, Asha Jenkins
}

\begin{abstract}
Department of Obstetrics \& Gynecology, Mahatma Gandhi Medical College and Research Institute, Pilliarkuppam, Pondicherry-607402, India
\end{abstract}

Received: 15 November 2012

Accepted: 11 December 2012

*Correspondence:

Dr. Seetesh Ghose,

Email: ghoseseetesh@gmail.com

\begin{abstract}
26 years, primigravida, with second degree of uterine prolapse attended to the emergency obstetrics outpatient department, in latent phase of labour. After 6 hours of admission, she entered into active phase of labour and membranes ruptured spontaneously. In spite of adequate uterine contractions, antiedema measures cervix did not dilate further. Finally, she delivered after giving Duhrssen's incision.
\end{abstract}

Keywords: Primigravida, Uterovaginal prolapse, Duhrssen's incision

\section{INTRODUCTION}

Prolapse is a common complaint of elderly multipara in gynecological practice. There are reports of prolapse occurring in multigravida. But it is a rare event in primigravida. Although a rare occurrence, there is still a need for obstetricians to be aware of the management of uterine prolapse which allows for an uneventful pregnancy, labour and delivery.

\section{CASE REPORT}

Mrs. X of 26 years, primigravida, a labourer by occupation with a complain of pain abdomen for one day, attended to the emergency obstetrics outpatient department of Mahatma Gandhi Medical College and Research Institute, Pondicherry, India, on $26^{\text {th }}$ May 2011 at 3.00 PM.

She was married for 2 years. It was a nonconsanguineous marriage. She was neither immunized nor had any antenatal visit throughout her pregnancy. Her last menstrual period was on $17^{\text {th }}$ August 2010 and expected date of delivery was on $24^{\text {th }}$ May 2011. Her period of gestation was 40 weeks and 2 days on the date of presentation to the hospital. Her $1^{\text {st }}, 2^{\text {nd }}$ and $3^{\text {rd }}$ trimesters were uneventful. There was no significant past history or family history of prolapse.
On examination, her vitals were stable. The uterus was of term size with contractions of 1-2 lasting for 10-20 seconds in 10 minutes. The FHR was 144/BPM. The cervix was visible at the introitus without separating the labia majora. It was partially effaced, soft in consistency, central in positions and internal os was $1.5 \mathrm{~cm}$ dilated. The membranes were intact and vertex was at ' 0 ' station.

A diagnosis of primigravida at 40 weeks and 2 days period of gestation was POG, with $2^{\text {nd }}$ degree uterovaginal prolapse in latent phase of labour was made. She was observed for spontaneous progression of labour with intermittent monitoring of FHR. After $6 \mathrm{hrs}$ of admission, she entered into active phase of labour and membranes ruptured spontaneously. At that time cervix was $75 \%$ effaced but anterior lip was edematous, internal os was $3 \mathrm{~cm}$ dilated, vertex was at the perineum and liquor was clear. Inspite of adequate uterine contractions, antiedema measures like intravenous valethamate bromide and local injection of hyaluronidase cervix did not dilate further. So Duhrssen's incision i.e. three surgical incisions of an incompletely dilated cervix, corresponding roughly to 2-, 6-, and 10-o'clock, used as a means of effecting immediate delivery of the fetus when there is an entrapped head during a delivery, was given and she delivered a term male baby, $2.1 \mathrm{~kg}$ at $2.00 \mathrm{am}$ on $27^{\text {th }}$ May 2011. 
Her postnatal period was uneventful. Vagina was packed with MgSo4 \& glycerine for 7 days. At discharge, uterus was involuted; cervix was at the level of introitus. Patient was advised to review in the OPD after 6 weeks.

\section{DISCUSSION}

Pelvic organ prolapse is the downward displacement of structures that are normally located at the level or adjacent to the vaginal vault. ${ }^{1}$ Uterine prolapse that occurs during pregnancy is a rare condition. Fewer than 300 cases have been reported in the literature, mostly before the 1970s. Previous estimates have put the incidence of uterine prolapse in pregnancy at 1 in 1000015000 deliveries worldwide. ${ }^{2,3}$ Incidence in India is 1 in $250 .^{4}$ Predisposing factors are atrophy of the supporting tissue at the climacteric, injury sustained during child birth, congenital or developmental weakness of the supports, chronic cough, constipation, ascites, tumour formation, lifting heavy weights can precipitate the onset of prolapse if weakness is already present. $^{5}$ Complications of pregnancy with prolapse are abortion, retention of urine, PROM, chorioamnionitis, early rupture of membranes, cervical dystocia, prolonged labour, obstructed labour, operative interference, sub-involution and uterine sepsis. ${ }^{4}$ Management options available are pessary treatment till 18-20 weeks, foot end elevation and antiedema measures like local application of glycerine \& acriflavine antenatally. During labour besides bed rest, antiedema measures, prophylactic antibiotics, manual stretching of the cervix and Duhrssens's incision is given if the head is deeply engaged and cervix remains undilated. Whereas LSCS is done if head is high up. Again in puerperium, ring pessary is applied till involution is complete along with prophylactic antibiotics. ${ }^{4}$ A case series of three pregnancies with prolapse by Haywood revealed that all happened in multigravida with history of prolonged labour and instrumental deliveries. ${ }^{6}$ Whereas salient features of this case are, it has happened in primigravida without any predisposing factors and outcome was uneventful antenatal period with a term delivery. Probably in our case of prolapse, which was pre-existing, got aggravated during pregnancy.

\section{REFERENCES}

1. Zimmerman CW. Pelvic organ prolapse: basic principles. In: Rock JA, Jones HW, editors. TeLinde's operative gynecology. 10th ed. Philadelphia: Lippincott Williams \& Wilkins;2008:854.

2. Mufarrij IK, Keettel WC. Prolapse of the uterus associated with pregnancy. Am J Obstet Gynecol 1957;73:899-903.

3. Kibel I, Wallace D. Abruptio placentae with multiple complications; a case report. Harlem Hosp Bull 1956;9:65-8.

4. DC Dutta. Text book of Obstetrics, $7^{\text {th }}$ Edition, India, New Central Book Agency Pvt. Ltd, 2011.

5. Kumar P, Malhotra N. eds. Jeffcoate's principles of gynaecology. $7^{\text {th }}$ ed. New Delhi: Jaypee;2008.

6. Brown HL. Cervical prolapse complicating pregnancy. J Natl Med Assoc 1997;89:346-8.

DOI: $10.5455 / 2320-1770 . i j r \operatorname{cog} 000412$

Cite this article as: Ghose $\mathrm{S}$, Samal S, Coumary S, Pallavee P, Jenkins A. Utero-vaginal prolapse in primigravida: a case report. Int J Reprod Contracept Obstet Gynecol 2012;1:50-1. 